distance from the point of suspension. When the illumination on the pendulum was only two foot candles, the letter $E$ could only be seen about a quarter of the way down the pendulum. But when the illumination was increased to 100 foot candles the letter $E$ could be seen almost at the bottom of the pendulum. A connexion can thus be obtained between the speed of vision and illumination. Experiments were described on the effect produced by the vibration of public vehicles. When the vehicle was moving, an appreciable reduction both in the speed of reading and in visual acuity took place. Experiments made a few years ago by reading a newspaper in a train on the Bakerloo Railway when it was at rest and when it was running showed that in the former case the speed of reading was 220 words a minute and in the latter 140 words a minute. In this case the illumination was two foot candles. Tests carried out in trains and buses under similar conditions about the same time gave similar results, showing that there was an appreciable reduction in the speed of reading when the vehicle is in motion. Reading under vibratory conditions in a poor light is known to cause visual fatigue and is apt to produce headaches. We are glad to hear that in some of the London Underground railway coaches to-day, the illumination at reading level has been raised to about twenty foot candles. This automatically does much to mitigate the effects of vibration, so far as visual performance and comfort are concerned.

\section{English Folk Dance and Song Society}

THE recent amalgamation of the Folk Song Society with the English Folk Dance Society has been marked by the appearance of a new journal with the title Journal of the English Folk Dance and Song Society, under the editorship of Mr. Frank Howes. The contents of the first number are indicative of the policy which it is now considered desirable for the reorganised societies to pursue in common. The primary object which the original societies had in view was the collection and preservation of the remains of traditional songs and dances. This work now being regarded as completed, so far as can be seen, the main work of the joint society on its scientific side will be intensive comparative study of the material which has been collected. In the first issue both activities, it is true, are represented. Ten more of the forty Gaelic songs collected by Miss Lucy Broadwood twenty-five years ago are published, as well as some English folk songs and dances recently recorded. On the comparative side, Mr. A. G. Gilchrist makes an exhaustive study of the Scottish and Northumbrian ballad Lambkin, discussing its growth and origin in the light of some forty versions. Similar studies of no little interest to students of culture and of 'survivals' and their distribution are Miss Violet Alford's record of the form and distribution of the Farandole in the south of France and in Spain and the study of the sword-dance by Dr. R. Wolfram of Vienna, who connects it with the initiation ceremony, seeing in the decapitation of the 'fool' the ritual death of initiation rather than the memory of a fertility sacrifice.

\section{Sadi Carnot, I796-I832}

IN La Nature of February 1, under the title "Grandeur et Modestie d'un savant Français : Sadi Carnot", M. Roger Vène gives a sketch of the life and character of the young French engineer who wrote the famous essay "Réflexions sur la puissance motrice du feu". Carnot was only twenty-eight years of age when he published the essay, and he died of cholera eight years later. According to the regulations, the clothes and papers belonging to the victims of the cholera epidemic which swept through Paris in 1832 were to be destroyed, but fortunately some of Carnot's manuscripts were saved by his friend Clapeyron. Born in the Petit Luxembourg when his father, Lazare Carnot, was a member of the Directory, Sadi had a brilliant career as a student of the Ecole Polytechnique but was too young to take part in the Napoleonic Wars, and his life was spent mainly in the routine of the barracks. The extracts given by M. Vène reveal a charming personality. The article is accompanied by a portrait of Carnot at the age of seventeen years. An article on Carnot appeared in our columns on August 20, 1932 (p. 266).

\section{Plant Pathology at Rothamsted Experimental Station}

THE Committee of Management of the Rothamsted Experimental Station recently decided to reorganise the old Department of Mycology, started in 1918 under the charge of Dr. W. B. Brierley, now professor of agrieultural botany at the University of Reading, and to constitute it a Department of Plant Pathology with Dr. J. Henderson Smith as head. Dr. Henderson Smith studied medicine at Balliol College, Oxford, and then proceeded to the University of Edinburgh, where he took his medical degree; he was then awarded the Philip Walker studentship in pathology, which he held at Oxford until his appointment first as bacteriologist at the Lister Institute and afterwards as plant pathologist in the Mycology Department at Rothamsted. He has published numerous papers on animal pathology, especially immunity and bacteriology, and on plant pathology, especially virus diseases.

\section{Motor-Car Speed Record}

ON February 22, Sir Malcolm Campbell broke his own motor-car speed record on Daytona Beach, Florida, in his car the Blue Bird. On the southward run Sir Malcolm covered the mile in $13 \cdot 16$ sec. and in the northern run in $13.60 \mathrm{sec}$. His mean speed worked out at $272 \cdot 108$ miles per hour, thus being well ahead of his record of 253.978 miles per hour set up last year. The Blue Bird is fitted with a RollsRoyce engine developing 2,350 H.P. at 3,200 R.M.P. The engine has a bore of 6 in. and a stroke of $6 \cdot 6$ in. This type of engine was also installed in the aeroplane which won the Schneider Trophy for Great Britain and in the machine in which Flight-Lieut. Stainforth achieved the world's present air speed record of $407 \cdot 5$ miles per hour.

\section{British Fresh-Water Fishes}

THE Trustees of the British Museum have published a second edition of their "Guide to the British 